\title{
CLAY MINERALOGY AND GEOCHEMISTRY OF CONTINENTAL BENTONITE AND THEIR GEOLOGICAL IMPLICATIONS, BOA VISTA, CAMPINA GRANDE, PB
}

\author{
TUMKUR RAJARAO GOPINATH*, HANS DIETER SCHUSTER* and WALTER KLAUS SCHUCKMANN**
}

\begin{abstract}
Bentonitic clay deposits of the Boa Vista region, Parafba, occur in small basins distribuited over a distance of $10 \mathrm{~km}$ and are surrounded by Tertiary basalts to the East and Precambrian granites and gneisses to the west. Clay minerals smectite, illite, and kaolinite are most aboundant in these sediments. The bentonite deposits of the East are richer in smectite ( 93 to $96 \%$ ) with illite making up the rest of the rock. In the Western part, smectite content decreases ( 73 to $85 \%)$ with higher contents of illite $(8$ to $11.5 \%)$ and kaolinite (6.6 to $14.6 \%$ ). The chemical composition of bentonite is apparently controlled by its mineralogy. Clay deposits in the West are enriched in $\mathrm{Al}_{2} \mathrm{O}_{3}, \mathrm{Fe}_{2} \mathrm{O}_{3}, \mathrm{TiO}_{2}$, and $\mathrm{K} 2 \mathrm{O}$ and in the East in $\mathrm{SiO}_{2}$, $\mathrm{CaO}$, and $\mathrm{K}_{2} \mathrm{O}$. The chemical differences between the deposits become clearer with discriminant function analysis performed over the groups of samples belonging to each area. Analysis of altered basalts associated with the bentonite shows that the illite and smectite have formed at the expense of volcanic glass and ferromagnesian minerals during the diagenesis. The Boa Vista bentonite deposits were formed as a result of the devitrification of glassy pyroclastics within small fresh water basins. Some of these basins were open to external influence resulting in the accumulation of clastic sediments along with detrital kaolinite. Other basins acted as closed systems with minimum leaching and negligible detrital accumulations.
\end{abstract}

RESUMO MINERALOGIA DE ARGILAS E GEOQUÍMICA DE BENTONITA CONTINENTAL E SUAS IMPLICACÕES GEOLÓGICAS, BOA VISTA, CAMPINA GRANDE, PB. As argilas bentoníticas de Boa Vista, Campina Grande, Paraba, formam pequenos depósitos distribuídos numa distância de $10 \mathrm{~km}$. As rochas encaixantes sāo o derrame basáltico do Terciário no lado leste e os granitos e gnaisses do Pre-Cambriano a oeste. A argila é çaracterizada pela predominância dos argilo-minerais esmectita, illita e caulinita. O argilo-mineral esmectita é mais abundante nos depositos do leste (de $93 \%$ a $96 \%$ ) com a illita perfazendo o restante. Nos depositos do oeste, o teor de esmectita é menor (de $73 \%$ a $85 \%$ ) com aumento nos conteúdos de illita e caulinita. A composição mineralógica controla a composição química de argila. As argilas do oeste são ricas em $\mathrm{Al}_{2} \mathrm{O}_{3}, \mathrm{Fe}_{2} \mathrm{O}_{3}, \mathrm{TiO}_{2}$ e $\mathrm{K}_{2} \mathrm{O}$, e do leste em $\mathrm{SiO}_{2}, \mathrm{CaO}_{\text {e }} \mathrm{K}_{2} \mathrm{O}$. As diferenças químicas se tornam evidentes pela análise de função discriminante das amostras de bentonita. $\mathrm{O}$ basalto decomposto associado à bentonita contém os argilo-minerais illita e esmectita resultantes da alteraçăo de vidro vulcânico e minerais ferromagnesianos. As argilas bentoníticas da regiäo são produtos de devitrificação dos materiais piroclásticos em pequenas bacias continentais. Algumas das bacias foram abertas às influências externas resultando a acumulação dos sedimentos clásticos junto com caulinita detrítica. Outras bacias foram sistemas fechados com taxa mínima de lixiviação e pouca acumulaçăo de detritos.

\section{INTRODUCTION}

The bentonite deposits of the Boa Vista district, Campina Grande, Paraíba, occur in small basins that are distribuited over a distance of $10 \mathrm{~km}$ along E-W direction. These deposits are designated geographically, from east to west, as Juá, Lages, and Bravo in the region (Fig. 1).

Various suggestions have been made as regards to the origin of these bentonites. Studies carried out by Caldasso $(1965,1979)$ lead him to conclude that the alteration of plagioclase and ferromagnesian minerals during weathering of basalt gave rise to the bentonite. According to him, the alteration took place in a lagoonal environment under alkaline conditions. Based on field studies, Pinto \& Pimentel (1968) concluded that the bentonite originated from the weathering of basalt associated with the clay deposits in the region. Extensive field and petrological investigations lead Gopinath et al. (1981) to conclude that the bentonites were formed from the alteration of glassy pyroclastics within topographic lowlands. These pyroclastics were supplied along with the lava flows through volcanic activity confined to the eastern part of the study area.

The purpose of this paper is to present chemical and clay mineralogical composition of the bentonites and associated rocks, and to discuss their implications in understanding the nature and origin of these clay deposits.

GEOLOGICAL SETTING The bentonite deposits of the Boa Vista district occur within irregularly distribuited basins whose maximum diameter is $500 \mathrm{~m}$ and a maximum

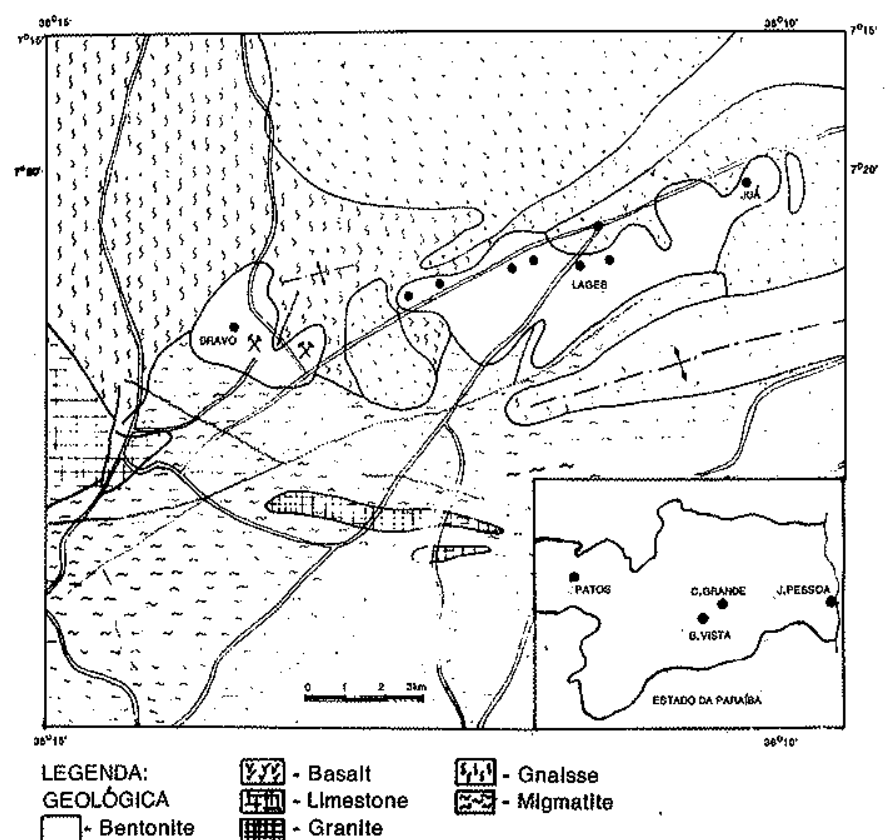

Figure I - Geologic map of the bentonite occurrence area showing locations of the deposits studied in this work (modified from Pinto \& Pimentel 1968)

* Departamento de Mineraçăo e Geologia/CCT, Universidade Federal da Parafba. CEP 58100, Campina Grande, PB

** Centro de Geociências, Universidade Federal clo Pará. CEP 66000, Belêm, PA 


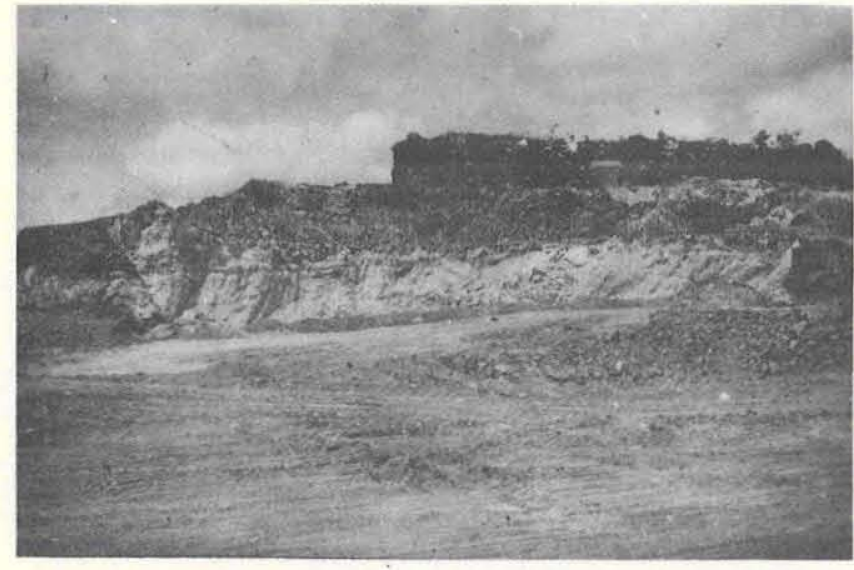

Photo I-Thick intercalations of sand and silt among bentonite beds, Bravo area

depth of $10 \mathrm{~m}$. The average thickness of the clay sequence varies from 2 to $7 \mathrm{~m}$.

A wide range of color variations can be observed among the clay sequences and some of the characteristic colors are red, green, and brown. The bentonite and associated sediments (layers of sand, silt, and chalcedony) show horizontal stratification (Photo 1). The clay sequence of Juá and Lages in the eastern part of the area are enclosed by basalt flows which tend to be highly vesicular, scoriaceous, and glassy in nature. Near the contact with the clay, the basalt is gray and has become soft due to the alteration and in one of the deposits a bed of conglomerate containing only basalt pebbles is observed (Photo 2). In the upper portions of the clay sequences in the Juá and Lages areas occur small basins of rhythmic intercalations of clay and chalcedony (Photo 3).

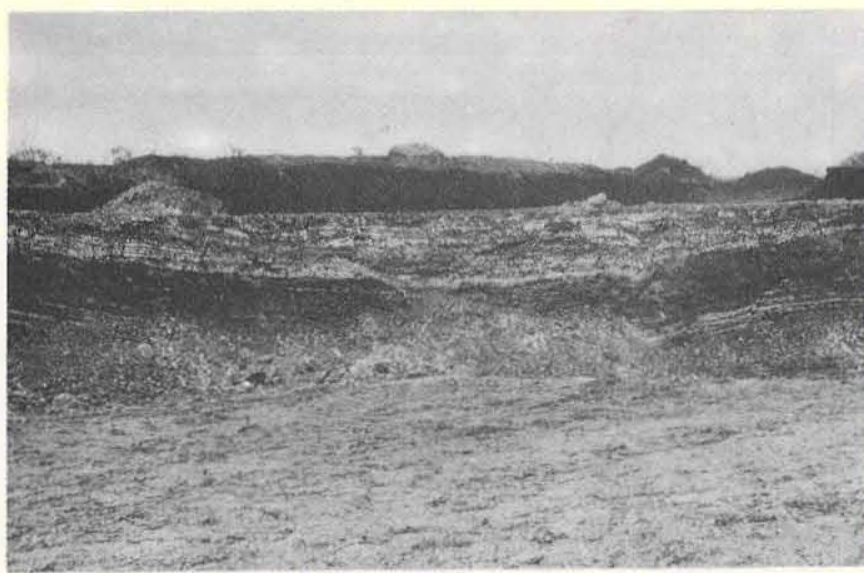

Photo 3 - Interlaminated chalcedony and clay basins overlying the bentonite sequence, Lages area

In the western part of the study area (Bravo), the bentonite sequence is underlain and enclosed by the Precambrian granites and gneisses. Throughout the sequence, the clay layers are interbedded with sandstones and siltstone beds of varying thickness. A detailed study of this clastic sequence with respect to its sedimentary structures, texture, lithology, and geometry showed that the sedimentation of coarse clastic sediments took place in an alluvial fan environment (Gopinath et al. 1979). Within the clay deposits of the Bravo area there are in situ silicified fossil trees (Photo 4).

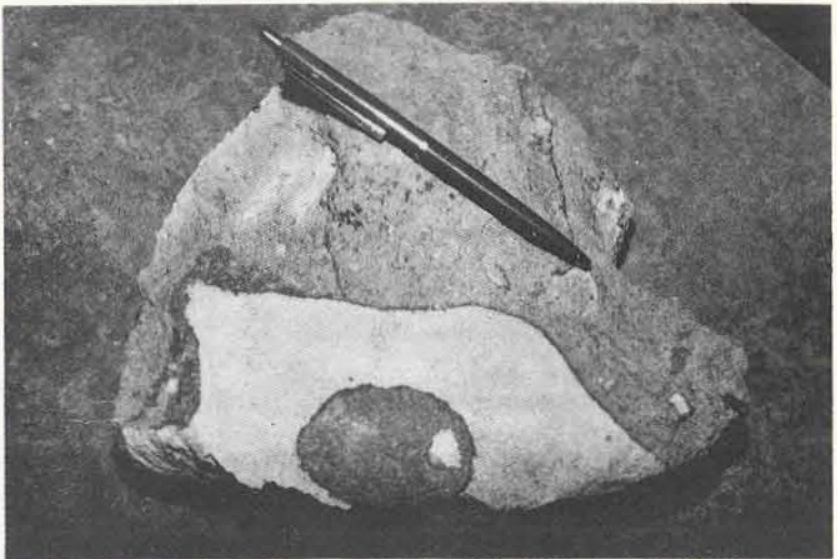

Photo 2 - Conglomerate with basalt pebble below the bentonite sequence. lages area

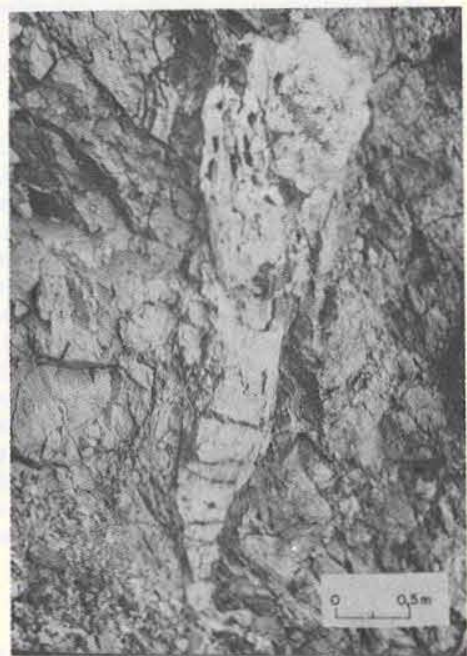

Photo 4 - Petrified tree within the bentonite deposit, Bravo area

The thin sections of the basalt were studied microscopically to determine its nature and genetic relationship with the associated bentonite deposits. A total of 25 samples collected from various parts of the measured sections were analyzed. The percentage abundance of each constituent was calculated by point counting of 300 points over the thin section and the relative frequency of each component is shown in table 1 .

Table 1 - Mineralogical composition of the basalt flow associated with the bentonite deposits

\begin{tabular}{|c|c|c|c|c|c|}
\hline Component $^{\text {Rock }}$ & 1 & 2 & 3 & 4 & 5 \\
\hline Volcanic glass & 51.0 & 70.0 & 57.3 & 79.5 & 1.5 \\
\hline Plagioclase & 44.5 & 17.5 & 21.6 & 1.5 & 43.5 \\
\hline Olivine & - & 9.5 & 14.4 & - & 22.5 \\
\hline Augite & - & 3.0 & 7.0 & - & 11.0 \\
\hline Oxides & 4.5 & - & - & - & 21.5 \\
\hline Basalt fragments & - & - & - & 19.0 & - \\
\hline
\end{tabular}

1. Basalt under bentonite (10 samples); 2. Top of basalt flow, Juá (5); 3. Bottom of basalt flow, Juá (4); 4. Lapilli, Juá (2); 5. Basalt flow, Lages (4) 


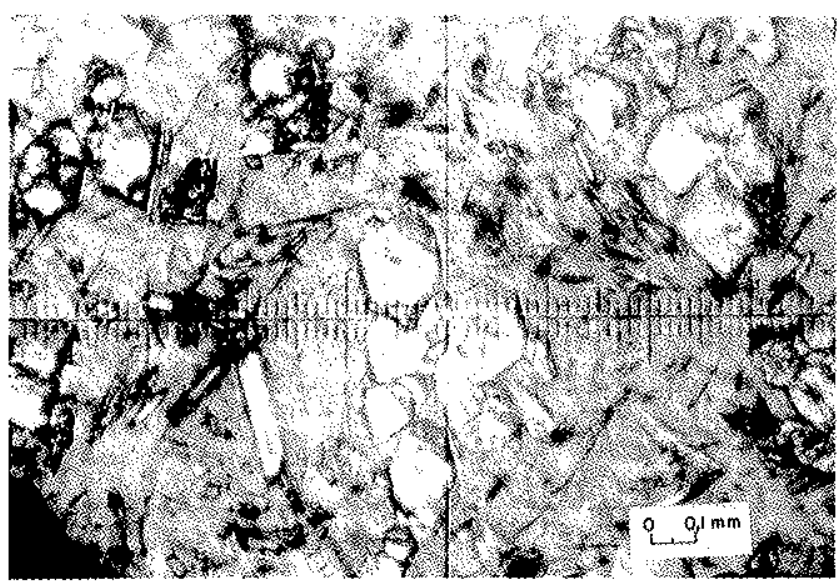

Photo 5 - Photomicrograph of basalt thin section showing glassy matrix with crystals of plafioclase and olivine

The basalt that occur below the bentonite sequence is rich in volcanic glass and plagioclase (Photo 5). The volcanic glass is altered to microcrystalline quartz and clay minerals. The basalt flow that occurs on the flanks of the clay deposits in the Juá area tend to be highly vesicular and glassy with columnar joints and flow structures (Photo 6). These rocks

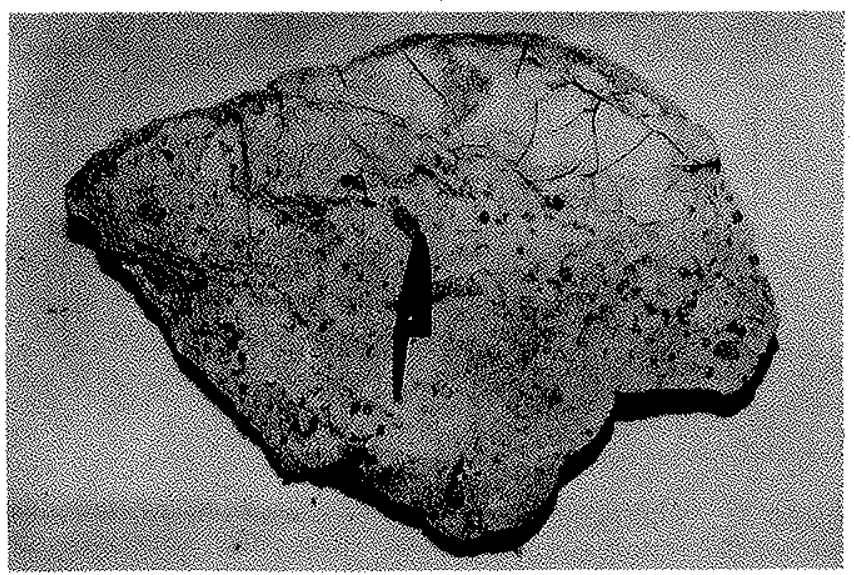

Photo 6-A sample of the scoriaceous basalt associated with the bentonite of the Lages area

contain abundant glass with minor amounts of plagioclase and ferromagnesian minerals (Tab. 1, columns $2 \& 3$ ). On top of the flows scattered blocks of lapilli occur, which contain volcanic glass and basalt rock fragments (Táb. 1 , column 4 , and Photo 7).

The basalt flows of the Lages area are generally aphanitic and non-vitreous and are different lithologically from that of Juá area by not containing as much glass. Mineralogically these rocks are abundant in plagioclase, olivine, and augite (Tab. 1, column 5).

Based on the petrological differences observed in the flows one can differentiate two sets of flows: the first type, resulting from gaseous eruptions, gave rise to vitreous lavas and the pyroclastics (lapilli); the second type, resulting from quiet eruptions, gave rise to non-vitreous, aphanitic basalt.

ANALYTICAL TECHNIQUES The bentonites and associated detrital sediments and basalts were analyzed for clay minerals and chemical composition. For this purpose the

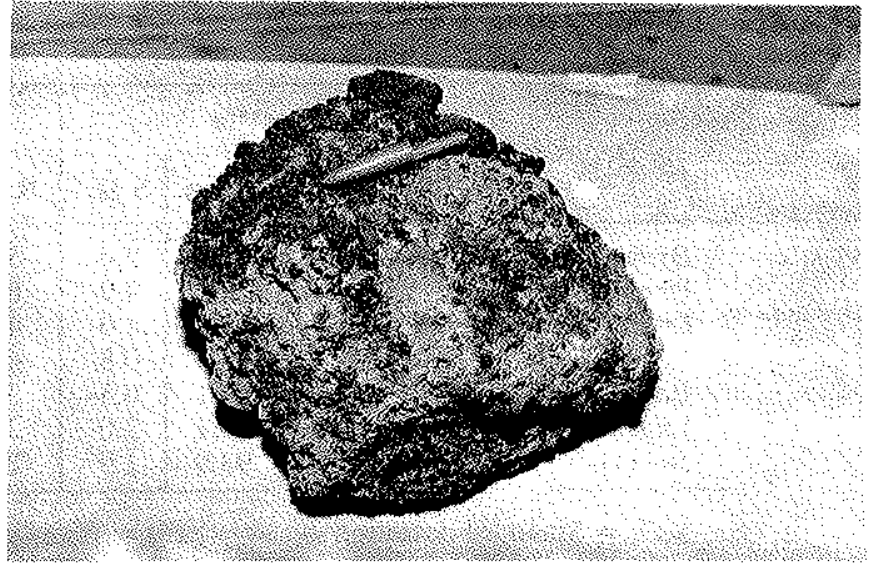

Photo 7 - Welded pyroclastics containing fragments of glass and vitreous basalt, Juá

samples were collected from eight deposits distribuited over the three areas (Juá, Lages, and Bravo) from East to West respectively (Fig. 1). Samples were collected vertically, from bottom to top, at the intervals of less than a meter in each deposit. The basalt samples, fresh and altered, were collected from flows that occur below and along the flanks of the bentonite deposits.

All the samples were analyzed for their minerals with $X$-ray powder diffraction on a Phillips vertical goniometer, using copper $\mathrm{K}$-alpha radiation $(1.5418 \AA)$ and a $\mathrm{LiF}$ monochromator in front of the proportional detector.

The chemical analysis for $\mathrm{Al}, \mathrm{Si}, \mathrm{P},-\mathrm{K}, \mathrm{Ca}, \mathrm{Ti}$, and $\mathrm{Fe}$ was done by $\mathrm{X}$-ray fluorescence spectrometry. Samples were prepared in the borate fusion techinique $(0.5 \mathrm{~g}$ sample $+1.5 \mathrm{~g}$ $\mathrm{Li} \mathrm{B}_{4} \mathrm{O}_{7}+1.5 \mathrm{~g} \mathrm{LiBO}_{2}$ ). The $\mathrm{K}$-alpha peak counts for the above elements were obtained on a Phillips PW410 spectrometer with $\mathrm{Cr}$ tube, dispersing crystals; $\mathrm{LiF}$ (for $\mathrm{K}$, $\mathrm{Ca}, \mathrm{Ti}$, and $\mathrm{Fe}$ ); $\mathrm{Ge}$ (for P), and TLAP (for $\mathrm{Al}$ and $\mathrm{Si}$ ); flow proportional detector and pulse-height discrimination. Calibration was done with international geochemical reference samples and no matrix correction was applied. The $\mathrm{Na}, \mathrm{Mg}$, and $\mathrm{Mn}$ were analyzed with atomic absorption utilizing a Zeiss Spectrophotometer model FMD-4.

MINERALOGY AND BULK CHEMISTRY OF BENTONITE The minerals identified in the bentonite samples of the Boa Vista region include smectite, illite, kaolinite, quartz; and feldspar. A detailed study made by Souza-Santos (1970) also demonstrated the presence of clay minerals montmorillonite, illite, kaolinite, and interlayered illite-montmorillonite in the bentonites of the Boa Vista district. This work also discusses the problems in determining the type of montomortillonite with $\mathrm{X}$-ray diffraction and gives a methodology that should be adopted for identifying types of montmorillonite, A semi-quantitative analysis of the clay minerals smectite, illite, and kaolinite was carried out and percentages of each clay mineral was computed (Pierce \& Siegel 1968). The abundance of the clay minerals in the deposits studied is shown in table 2 . The average content of the smectite among the three species varies from a minimum of $73.9 \%$ in the Bravo area to a maximum of $96.1 \%$ in the Lages region, whereas the illite content, in the bentonite samples of the Lages, tends to a minimum $(3.8 \%)$ and is higher in the Bravo area (11.5\%). The kaolinite is abundant and present only in the Bravo samples, where the maximum content tends to be $19.2 \%$ (Fig. 2).

In the Bravo region, the bentonites are underlained and surrounded by Precambrian granites and gneisses and in the 
Table 2-Clay mineral abundance in the bentonite deposits of Boa Vista, Campina Grande, PB

\begin{tabular}{l|c|c|c|c|c|c|c|c|c}
\hline \multirow{2}{*}{ Deposit } & \multicolumn{3}{|c|}{ Smectite } & \multicolumn{3}{c|}{ Illite } & \multicolumn{3}{c}{ Kaolinite } \\
\cline { 2 - 9 } & Range (\%) & Mean & S.D. & Range (\%) & Mean & S.D. & Range (\%) & Mean & S.D. \\
\hline Bravo-1 (6) & $83.4-86.9$ & 85.4 & 2,0 & $5.3-10.4$ & 8.5 & 1.98 & $1.7-10.5$ & 6.6 & 3.1 \\
Bravo-2 (6) & $69.5-81.5$ & 73.9 & 4.9 & $8.6-14.5$ & 11.5 & 2.3 & $8.0-19.2$ & 14.6 & 4.4 \\
Lages-1 (4) & $94.4-96.7$ & 95.3 & 1.0 & $4.8-5.6$ & 5.2 & 0.3 & - & - & - \\
Lages-2 (5) & $92.6-94.7$ & 93.4 & 0.8 & $4.9-6.7$ & 6.1 & 0.8 & $0.3-0.6$ & 0.4 & 0.1 \\
Lages-3(6) & $95.4-96.8$ & 96.1 & 0.5 & $3.3-4.4$ & 3.8 & 0.4 & $0.0-0.4$ & 0.2 & 0.1 \\
Lages-4 (3) & $91.9-96: 0$ & 94.1 & 2.0 & $3.9-7.4$ & 5.5 & 1.2 & $0.0-0.6$ & 0.3 & 0.1 \\
Juá(7) & $90.6-95.2$ & 93.9 & 1.9 & $2.5-6.6$ & 4.9 & 1.5 & - & - & - \\
\hline
\end{tabular}

S.D. = Standard deviation $\quad-\quad(6)=$ Number of samples

Lages and Juá regions they are enclosed by basalt flows. It is known that the kaolinite will form when there is a good drainage or leaching and a low pH environment (Grim 1968, Millot 1970, Garrels \& Mackenzie 1971, Souza-Santos 1975). Leaching tends to remove the principal mobile cations, leaving behind silicon and aluminium which tends to form kaolinite. However, if leaching was a characteristics of the basins in the Boa Vista region one would expect to find kaolinite in all the clay samples. Kaolinite is present as detected by $x$-ray diffraction, only in the Bravo deposits and is considered to be of detrital in nature. This detrital kaolinite was probably derived from the granitic source that enclose the Bravo bentonites. Kaolinite was not found in the Lages and Juá deposits because they are enclosed by basic rocks and the alteration of these rocks has produced illite and smectite rather than kaolinite (fig. 3).

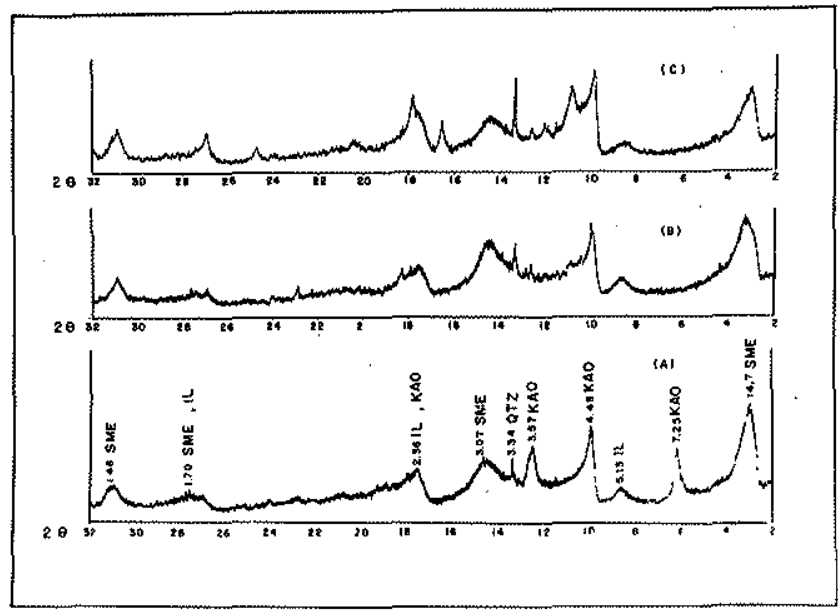

Figure 2 - Diffractogram of the bentonite samples representing Bravo (A), Lages (B), and Jua (C) areas, with smectite (SME), kaolinite (KAO), illite (IL), and quartz $(Q T Z)$

The clay mineral illite is found in varying proportions in all the deposits. The Bravo bentonites are higher in illite (maximum 11.5\%) as compared to the deposits of Juá and Lages (maximum 6.1\%). Illite, presumed to be of detrital origin, could have been derived either from the alteration of alkali feldspar in the granitic rocks or from the alteration of ferromagnesian minerals in the basalt flows. In figure 3 one can observe illite and smectite in the altered basalt. Apparently illite was originated from basaltic source in the Lages and Juá regions and from granitic source in the Bravo area. If the illite is of diagenetic origin its content is expected to be uniform in all the deposits. It is believed that the variation of illite contents is due to its detrital nature because

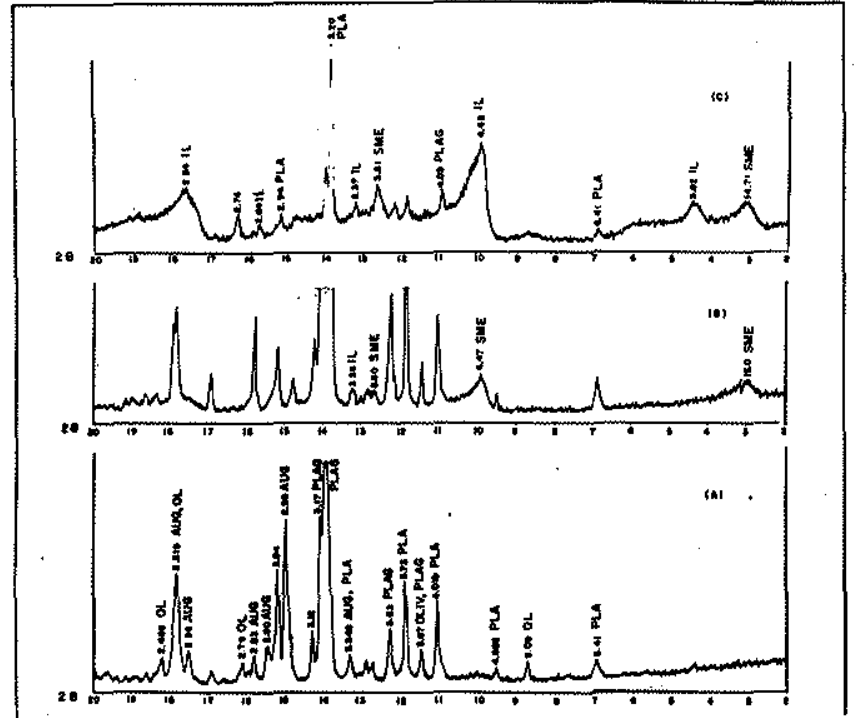

Figure 3 - Diffractogram of fresh (A), semi-altered (B), and altered $(\mathrm{C})$ basalt samples showing gradual disappearence of olivine (OL) and augite (AUG) and appearence of clay minerals with plagioclase (PLAG) being present in all samples

the quantity supplied depends on the source rock and weathering susceptibility.

CHEMISTRY OF BENTONITE The chemical composition of bulk samples of the clay is shown in table 3 . The following oxides were obtained from the chemical analysis: $\mathrm{SiO}_{2}, \mathrm{TiO}_{2}, \mathrm{Al}_{2} \mathrm{O}_{3}, \mathrm{Fe}_{2} \mathrm{O}_{3}, \mathrm{MnO}, \mathrm{MgO}, \mathrm{CaO}, \mathrm{Na} 2 \mathrm{O}$, $\mathrm{K}_{2} \mathrm{O}$, and $\mathrm{P}_{2} \mathrm{O}_{3}$. The average and standard deviation of each oxide was computed to determine the variation in chemical composition among the deposits. The clay samples of the Bravo-2 are homogeneous in color lack chalcedony intercalations within the clay beds. These clays are generally poorer in $\mathrm{SiO}_{2}(\overline{\mathrm{X}}=51.93 \%)$ and higher in $\mathrm{Al}_{2} \mathrm{O}_{3}(\mathrm{X}=$ $19.65 \%), \mathrm{K}_{2} \mathrm{O}(\overline{\mathrm{X}}=1.84 \%)$, and $\mathrm{Fe}_{2} \mathrm{O}_{3}(\bar{X}=10.35 \%)$ than other deposits because the clays contain alkali feldspar and are rich in illite and kaolinite when compared to other deposits (Elsinger \& Sellars 1981).

On the other hand, rest of the deposits contain relatively high $\mathrm{SiO}_{2}(\overline{\mathrm{X}}=59.45$ to $64.70 \%)$ and low $\mathrm{Al}_{2} \mathrm{O}_{3}, \mathrm{Fe}_{2} \mathrm{O}_{3}$, and $\mathrm{K}_{2} \mathrm{O}$ as compared to Bravo-2 occurence. This can be attributed to the scarcity of illite and absence of kaolinite and 
Table 3 - Major elements in the chemical composition of the bentonites, Boa Vista, PB

\begin{tabular}{l|rr|rr|rr|rr}
\hline \multicolumn{1}{c|}{ Oxides } & \multicolumn{2}{|c|}{ Bravo-1 } & \multicolumn{2}{c|}{ Bravo-2 } & \multicolumn{2}{c|}{ Lages } & \multicolumn{2}{c}{ Juá } \\
\hline \multicolumn{1}{c|}{$\%$} & Mean & S.D. & Mean & S.D. & Mean & S.D. & Mean & S.D. \\
\hline $\mathrm{SiO}_{2}$ & 62.12 & 5.78 & 51.93 & 1.71 & 64.70 & 9.79 & 59.45 & 5.52 \\
$\mathrm{TiO}_{2}$ & 0.78 & 0.15 & 1.33 & 0.06 & 0.67 & 0.30 & 1.20 & 0.42 \\
$\mathrm{Al}_{2} \mathrm{O}_{3}$ & 15.54 & 2.53 & 19.65 & 0.68 & 13.32 & 3.59 & 15.65 & 3.33 \\
$\mathrm{Fe}_{2} \mathrm{O}_{3}$ & 8.00 & 1.15 & 10.35 & 1.30 & 6.89 & 2.31 & 8.27 & 2.29 \\
$\mathrm{MnO}$ & 0.02 & 0.01 & 0.03 & 0.01 & 0.02 & 0.01 & 0.15 & 0.00 \\
$\mathrm{MgO}$ & 2.02 & 0.33 & 2.79 & 0.28 & 2.17 & 0.77 & 2.64 & 0.48 \\
$\mathrm{CaO}$ & 0.65 & 0.09 & 0.50 & 0.05 & 0.86 & 0.55 & 1.08 & 0.23 \\
$\mathrm{Na}_{2} \mathrm{O}$ & 0.63 & 0.12 & 0.79 & 0.09 & 1.04 & 0.56 & 0.68 & 0.29 \\
$\mathrm{~K}_{2} \mathrm{O}$ & 0.29 & 0.10 & 1.84 & 0.42 & 0.29 & 0.08 & 0.56 & 0.46 \\
$\mathrm{P}_{2} \mathrm{O}_{3}$ & 0.05 & 0.00 & 0.12 & 0.04 & 0.04 & 0.00 & 0.06 & 0.04 \\
$\mathrm{Ignition}$ & 10.18 & 1.57 & 11.59 & 1.08 & 10.24 & 3.15 & 11.63 & 2.64 \\
Total & $\mathbf{1 0 0 . 2 8}$ & & 100.92 & $\mathbf{1 0 0 . 2 4}$ & 101.37 \\
\hline
\end{tabular}

S.D. $=$ Standard deviation $-\mathrm{Fe}_{2} \mathrm{O}_{3}=$ Total iron

high smectite content in these clay samples. The bentonite beds are intercaled with chalcedony layers indicating enrichment of silica in the basin during clay formation, for that reason the Lages and Juá bentonites are relatively high in $\mathrm{SiO}_{2}$.

DISCRIMINANT FUNCTION ANALYSIS Although the clay deposits have different chemical compositions, it is difficult to be sure if these differences are significant. With this objective in mind, the chemical data were analyzed by multivariate statistical technique to bring out the subtle differences that may exist among the bentonite deposits of the Boa Vista district.

To analyze simultaneous fluctuations of the variables in a multicomponent system, it is necessary to use multivariate statistics, because it allows easy comparison of varied data gathered from many deposits. The discriminant function analysis was chosen to compare the chemical composition of the bentonite samples. For mathematical details, the reader is referred to Cooley \& Lohens (1962), King (1969), and Klovan \& Billings (1967). In this study, the coefficients of the discriminant function (canonical weights) are used to give empirical interpretations to the linear-discriminant function. In simple terms, the magnitude of the coefficient illustrates the relative importance of each variable in discriminating between groups (Klovan \& Billings op. cit.). The discriminant function analysis assumes that all groups are predetermined on the basis of other criteria.

For discriminant function analysis, the bentonite samples were grouped in to three classes: Juá, Lages, and Bravo, for the reason that each one is distinct geographically and geologically. A total of 10 variables were utilized in the analysis and they are percentages of $\mathrm{SiO}_{2}, \mathrm{TiO}_{2}, \mathrm{Al}_{2} \mathrm{O}_{3}$; $\mathrm{Fe}_{2} \mathrm{O}_{3}, \mathrm{MnO}, \mathrm{MgO}, \mathrm{CaO}, \mathrm{Na}_{2} \mathrm{O}, \mathrm{K}_{2}$, and $\mathrm{P}_{2} \mathrm{O}_{3}$. The statistical analysis was performed on the following combinations of the groups: Juá and Lages; Lages and Bravo; and Juá, Lages, and Bravo.

Results of the discriminant function analysis of the Juá, Lages, and Bravo are presented in figure 4, which is a plot of each sample relative to the first two discriminant functions. Although there is a considerable scattering of samples within each group, the segregation of the three groups is successfully achieved. It is clear from the figure that bentonite samples of each area are chemically distinct and so can be distinguished by their chemical composition characteristics.

The absolute values for the correlation between the input variables and discriminant functions $1 \& 2$-(Tab. 4, Fig. 4) demonstrate that the most effective discrimination takes place along discriminants function 1 (horizontal axis) between Juá and Lages, and along discriminant function 2 (vertical axis) between Bravo and Lages samples. The correlation coefficient shows that (larger its value, more probable it is) the variables important in bringing out the separation of the groups observed in figure 4 are: percentages of $\mathrm{TiO}_{2} ; \mathrm{Al}_{2} \mathrm{O}_{3}$; $\mathrm{Fe}_{2} \mathrm{O}_{3} ; \mathrm{CaO}$; $\mathrm{Na}_{2} \mathrm{O}$; and $\mathrm{K}_{2} \mathrm{O}$ (Tab. 4). The bentonites from Juá are relatively higher in $\mathrm{TiO}_{2}, \mathrm{Al}_{2} \mathrm{O}_{3}, \mathrm{Fe}_{2} \mathrm{O}_{3}, \mathrm{CaO}$ and $\mathrm{K}_{2} \mathrm{O}$ and poorer in $\mathrm{Na}_{2} \mathrm{O}$ than the Lages area clay (Tab. 5).

The Bravo samples are enriched in $\mathrm{TiO}_{2}, \mathrm{Al}_{2} \mathrm{O}_{3}, \mathrm{Fe}_{2} \mathrm{O}_{3}$, and $\mathrm{K}_{2} \mathrm{O}$ and are lower in $\mathrm{CaO}$ and $\mathrm{Na}_{2} \mathrm{O}$ than the Lages samples. The Lages area bentonite tends to contain very low $\mathrm{TiO}_{2}, \mathrm{Fe}_{2} \mathrm{O}_{3}$, and $\mathrm{K}_{2}$ and is high in $\mathrm{Na}_{2} \mathrm{O}$ amongst all the three groups analyzed. Thus, the chemical differences

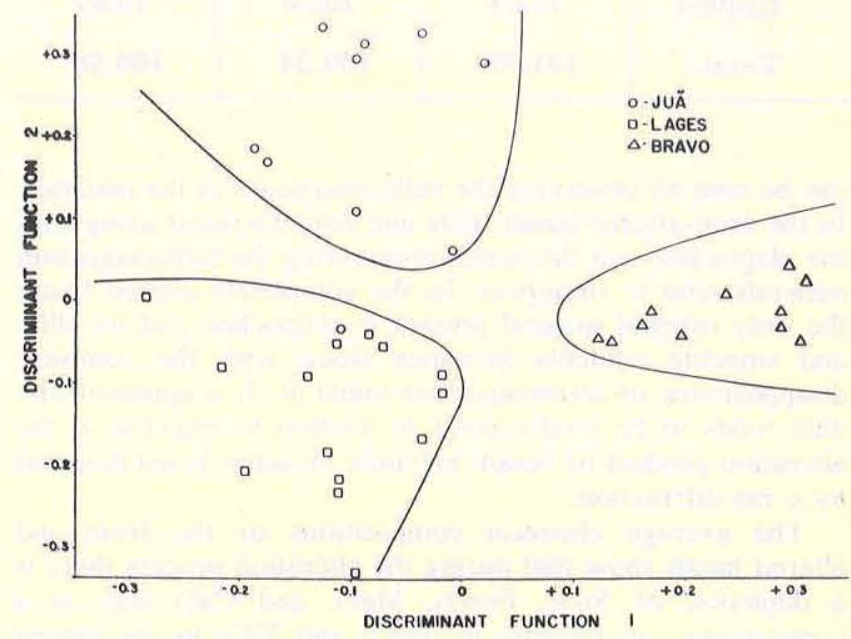

Figure 4 - Multiple discriminant function analysis of Juá, Lages, and Bravo samples

Table 4 - Correlation between input variables and discriminant functions Juá, Lages, and Bravo bentonites

\begin{tabular}{l|c|c}
\hline Oxides & $\begin{array}{c}\text { Discriminant } \\
\text { function 1 }\end{array}$ & $\begin{array}{c}\text { Discriminant } \\
\text { function 2 }\end{array}$ \\
\hline $\mathrm{TiO}_{2}$ & 0.25 & 0.61 \\
$\mathrm{Al}_{2} \mathrm{O}_{3}$ & 0.51 & 0.26 \\
$\mathrm{Fe}_{2} \mathrm{O}_{3}$ & 0.53 & 0.47 \\
$\mathrm{CaO}$ & 0.73 & 0.39 \\
$\mathrm{Na}_{2} \mathrm{O}$ & 0.21 & 0.36 \\
$\mathrm{~K}_{2} \mathrm{O}$ & 0.59 & 0.16 \\
\hline
\end{tabular}

characterize each clay deposit and thereby may help to classify the bentonites utilizing the chemical composition.

MINERALOGY AND CHEMISTRY OF BASALT In the Juá and Lages areas the basalt flows underlie and enclose the bentonite deposits. The basalts shows various degrees of alteration near the contact with the bentonite. The fresh basalt contains plagioclase, olivine, augite in addition to volcanic glass and iron oxides. Mineralogical and chemical analysis of altered and fresh basalts were carried out to trace the diagenetic alteration process of basalt during bentonite formation. Samples of fresh basalt, semi-altered, and completely altered basalts were examined by X-ray diffraction and the figure 3 shows the patterns of the three samples. The transformation of augite, olivine, and plagioclase 
Table 5-Major elements in the chemical composition of three groups of discriminant function analysis.

\begin{tabular}{c|r|r|r}
\hline $\begin{array}{c}\text { Oxides } \\
\%\end{array}$ & Juá & Lages & Bravo \\
\hline $\mathrm{SiO}_{2}$ & 59.45 & 64.70 & 57.03 \\
$\mathrm{TiO}_{2}$ & 1.20 & 0.67 & 1.06 \\
$\mathrm{Al}_{2} \mathrm{O}_{3}$ & 15.65 & 13.32 & 17.60 \\
$\mathrm{Fe}_{2} \mathrm{O}_{3}$ & 8.27 & 6.89 & 9.12 \\
$\mathrm{MnO}$ & 0.01 & 0.02 & 0.02 \\
$\mathrm{MgO}$ & 2.64 & 2.19 & 2.41 \\
$\mathrm{CaO}$ & 1.08 & 0.86 & 0.58 \\
$\mathrm{Na2O}$ & 0.68 & 1.04 & 0.71 \\
$\mathrm{~K} 2 \mathrm{O}$ & 0.56 & 0.29 & 1.07 \\
$\mathrm{P}_{2} \mathrm{O}_{3}$ & 0.06 & 0.04 & 0.09 \\
Ignition & 11.63 & 10.24 & 10.89 \\
Total & $\mathbf{1 0 1 . 3 7}$ & $\mathbf{1 0 0 . 2 4}$ & $\mathbf{1 0 0 . 5 8}$ \\
\hline
\end{tabular}

can be seen by observing the reflection peaks of the minerals. In the semi-altered basalt, illite and smectite occur along with the plagioclase and the peaks representing the ferromagnesian minerals tend to disappear. In the completely altered basalt the only original mineral present is plagioclase and the illite and smectite contents increases along with the complete disappearence of ferromagnesian minerals. It is apparent that illite tends to be predominant in relation to smectite as the alteration product of basalt; kaolinite presence is not detected by $\mathrm{x}$-ray diffraction.

The average chemical compositions of the fresh and altered basalt show that during the alteration process there is a depletion of $\mathrm{SiO}_{2}, \mathrm{Fe}_{2} \mathrm{O}_{3}, \mathrm{MgO}$, and $\mathrm{CaO}$ and, as a consequence, an increase in $\mathrm{Al}_{2} \mathrm{O}_{3}$ and $\mathrm{TiO}_{2}$ in the altered rocks (Tab. 6); this is caused by the alteration of ferromagnesian minerals and the formation of clay minerals such as illite and smectite. The $\mathrm{Na} 2 \mathrm{O}$ content remains almost unchanged in the rocks demonstrating the persistence of plagioclase during the alteration process.

Though the chemical difference between the fresh and altered basalt is obvious, the discriminant function analysis was performed to verify this difference (Fig. 5). It can be observed that within group chemical variations tend to be high in the altered basalt and low in the fresh basalt samples. This can be attributed to the processes that operate during the formation of fresh basalt (homogeneous processes) and altered basalt (divergent processes). The variables important in separating the groups according to the correlation coefficients are: percentages of $\mathrm{TiO}_{2}, \mathrm{Al}_{2} \mathrm{O}_{3}, \mathrm{Fe}_{2} \mathrm{O}_{3}, \mathrm{MgO}$, and $\mathrm{CaO}$ (Tabs. 6 and 7).

DISCUSSION AND CONCLUSIONS Variations in the clay mineralogy and the chemical composition observed within the bentonite deposits of the Boa Vista district can be attributed to a diversity of processes, characteristic of the continental environment in which the clays originated.

In the Bravo area, the bentonites are abundantly interstratified with detrital sediments (sand and silt), which are not observed in the other deposits. The granitic rocks that enclose the Bravo deposits supplied large quantities of sandy sediments to an open basin, and these sediments accumulated in an alluvial fan framework (Gopinath et al. 1979). The basaltic flow that encloses the Lages and Juá deposits inhibited the accumulation of detrital sediments within the existing closed basins. For this reason the Bravo Bentonites are richer in illite and kaolinite than the other deposits. The clay in the sandstones layers occuring within the bentonites of Bravo area are also abundant in kaolinite and illite indicating
Table 6 -Major elements in the chemical composition of fresh and altered basalt samples, Boa Vista, $P B$.

\begin{tabular}{c|r|r|r|r}
\hline Oxides & \multicolumn{2}{|c|}{ Fresh basalt } & \multicolumn{2}{c}{ Altered basalt } \\
\hline$\%$ & Mean & S.D. & Mean & S.D. \\
\hline $\mathrm{SiO}_{2}$ & 49.13 & 1.03 & 46.70 & 3.00 \\
$\mathrm{TiO}_{2}$ & 1.84 & 0.19 & 2.75 & 0.27 \\
$\mathrm{Al}_{2} \mathrm{O}_{3}$ & 14.26 & 0.39 & 18.62 & 2.18 \\
$\mathrm{Fe}_{2} \mathrm{O}_{3}$ & 10.94 & 0.61 & 6.68 & 1.53 \\
$\mathrm{MnO}$ & 0.15 & 0.06 & 0.09 & 0.00 \\
$\mathrm{MgO}$ & 6.85 & 0.95 & 2.15 & 0.64 \\
$\mathrm{CaO}$ & 8.67 & 0.59 & 4.02 & 2.25 \\
$\mathrm{Na2O}$ & 2.76 & 0.34 & 2.47 & 1.09 \\
$\mathrm{~K} 2 \mathrm{O}$ & 0.65 & 0.26 & 0.51 & 0.29 \\
$\mathrm{P}_{2} \mathrm{O}$ & 0.11 & 0.02 & 0.24 & 0.19 \\
Ignition & 4.45 & 1.24 & 14.80 & 4.02 \\
Total & 99.81 & & $\mathbf{9 9 . 0 3}$ & \\
\hline No. samples & 11 & & 13 & \\
\hline
\end{tabular}

S.D. = Standard deviation

Table 7 - Correlation between input variables and discriminant function-fresh and altered basalt

\begin{tabular}{c|c}
\hline Oxides & $\begin{array}{c}\text { Discriminant } \\
\text { function 1 }\end{array}$ \\
\hline $\mathrm{Al}_{2} \mathrm{O}_{3}$ & 0.90 \\
$\mathrm{Fe}_{2} \mathrm{O}_{3}$ & 0.87 \\
$\mathrm{CaO}_{\mathrm{TiO}}$ & 0.83 \\
$\mathrm{MgO}$ & 0.92 \\
\hline
\end{tabular}

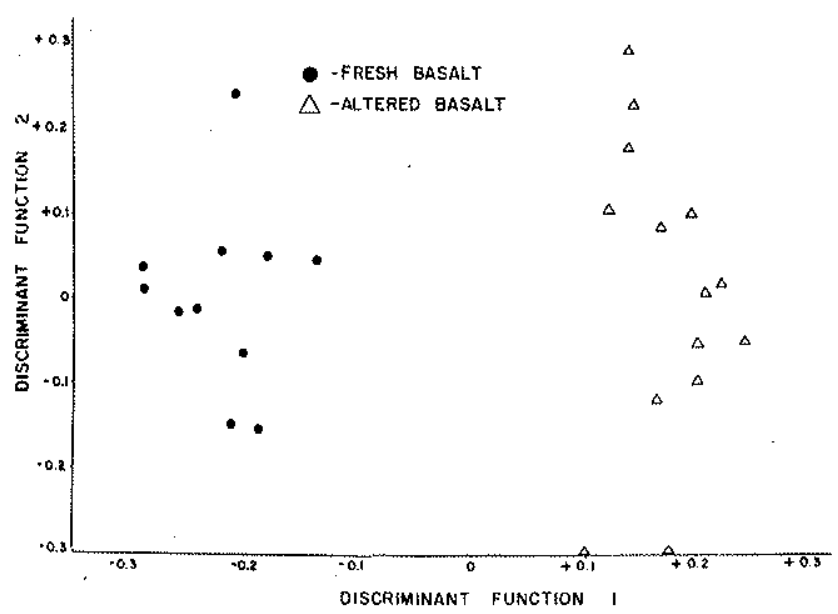

Figure 5-Multiple discriminant function analysis of fresh and altered basalt samples

an external source for these two clay minerals (Fig. 6). Extensive rhythmic interlaminations of chalcedony and very little of sandy sediments in the bentonites of the eastern region (Lages and Juá) show the chemical (evaporitic) nature of the environment that prevailed in these basins. Precipitation of silica occured periodically as a function of silica concentration and alkaline conditions, which in turn controlled by climatic changes. Leaching in these basins was 


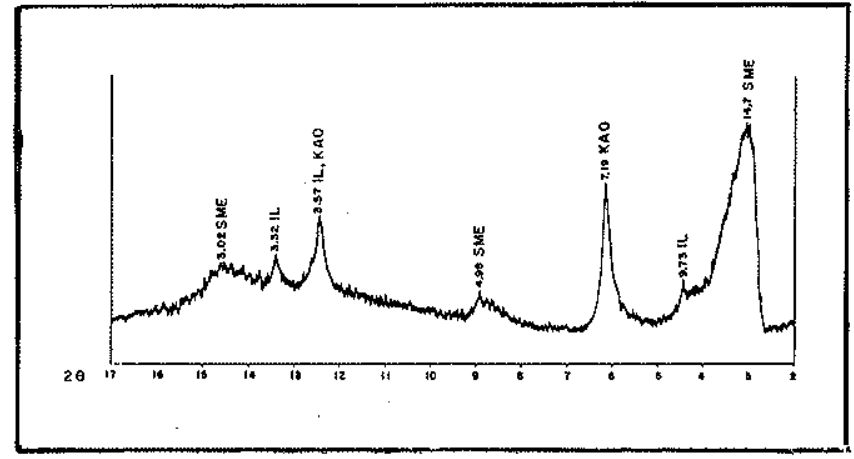

Figure 6-Diffractogram showing clay minerals in sandstones, Bravo area

minimum, inhibiting the formation of kaolinite (Loughnan 1969). The clay deposits of this area contain smectite as predominant clay minerals, with kaolinite and illite occuring in traces. These results are in agreement with previous studies of bentonites from these areas by Souza-Santos $(1970,1975)$.

The bentonites are chemically heterogeneous and show considerable variation within each deposit. However, the deposits of each area tend to be chemically distinct from the other deposits in the two areas. Important oxides that bring about the differences among the deposits are $\mathrm{TiO}_{2}, \mathrm{Al}_{2} \mathrm{O}_{3}$, $\mathrm{CaO}, \mathrm{K}_{2} \mathrm{O}$, and $\mathrm{Na}_{2} \mathrm{O}$. The $\mathrm{Bravo}$ bentonites are high in $\mathrm{Al}_{2} \mathrm{O}_{3}, \mathrm{~K}_{2} \mathrm{O}$, and $\mathrm{Fe}_{2} \mathrm{O}_{3}$, as a function of high kaolinite and illite contents. The bentonites of Juá and Lages having traces of illite and kaolinite are poorer in $\mathrm{Al}_{2} \mathrm{O}_{3}$ and $\mathrm{Fe}_{2} \mathrm{O}_{3}$.

The weathering of basalt under varying climatic conditions has been investigated extensively (Bates 1962, Hay. \& Jones 1972, Kojiwada 1987, Eggleton et al. 1987). The diagenesis of basalt (basalt-water system) is less well understood and studies carried out are few (Walker 1960, Hein \& Scholl 1978, Benson \& Teague 1982). In Boa Vista region basalt flows that underlie the bentonite are believed to have undergone diagenesis and the diagenetic change observed is discussed here. Also to demonstrate that the weathering of basalt and accumulation of the weathered products did not result in the bentonite deposits as believed by some authors. During diagenesis, illite and smectite are the principal minerals formed with plagioclase remaining stable throughout (Fig. 3). Basalt has lost $\mathrm{Fe}, \mathrm{Mg}$, and $\mathrm{Ca}$ and has relatively gained $\mathrm{Ti}$ and Al during the transformation. Although the
$\mathrm{Al}_{2} \mathrm{O}_{3}$ content is sufficiently high, kaolinite has not formed dur to lack of leaching in the environment. Very little change is noted in the $\mathrm{Na}_{2} \mathrm{O}$ content between altered and fresh basalt, which shows the stability of plagioclase during diagenesis. The change in the $\mathrm{SiO}_{2}$ content is negligible where altered basalt being poorer $(46.7 \%)$ than the fresh basalt $(49.13 \%)$ in $\mathrm{SiO}_{2}$ content. It is known that the weathering of basalt produces, under moderate leaching, halloysite, allophane, and amorphous hydrated aluminium silicate with alumina and silica gels, serpentinite of trioctahedral smectite (Bates op. cit., Hay \& Jones op. cit.). When the leaching approaches its optimum the products are gibbsite, lateritic minerals, amorphous alumina, and ferric hydrates as observed in the Hawaiian Island basalts. According to Benson \& Teague (op. cit.) diagenesis of basalt has lead to formation of iron rich smectite, clinoptilolite, and silica. Apparently weathering tend to produce a relatively complex mineral assemblage and the diagenesis tend to produce a simple mineral assemblage. The alteration products observed in the basalt in this study point out to diagenesis rather than weathering of basalt in the Boa Vista district. The bentonite of Boa Vista was formed due to divitrification of glassy pyroclastics within small fresh water basins rather than by accumulation of weathered products of basalt. The pyroclastics were silica poor and magnesium rich favoring the alteration process to give rise to the bentonitic clay deposits (Ross \& Hendricks 1945, Sokolov 1966, Slaughter \& Early 1965, Grim \& Guven 1978).

Mineralogical and chemical characteristics observed in the bentonites can be atributed to continental processes. In the marine environment chemical/mineralogical diversities are minimum due to limited external influences. In the Western part of the Boa Vista district bentonites were formed in open basins with considerable external influence. In the Eastern part, bentonites formed in closed basins minimum leaching and with very little external influences, thus the bentonite deposits of Juá and Lages areas are relatively more homogeneous and pure in clay minerals than the Bravo clay deposits which are characterized by non-clay mineral impurities.

Acknowledgements Authors acknowledge the CNPq for its support and encouragement through research scholarship (Bolsa de Estudo) to all three authors and research grants (Auxilio à Pesquisa) (Proc. 06000/18440/30, and 40.0155/87.7-GL) to Dr. Gopinath. The X-ray diffraction and fluorescence analyses were carried out at the Centro de Geociências, Universidade Federal do Pará, Belém.

\section{REFERENCES}

BATES, T,F, 1968. Halloysite and gibbsite formation in Hawaii. In: NAT. CONF. CLAY AND CLAY MINERALS. Proceed... p. 307-314. (Number 9)

BENSON, L.V \& TEAGUE, L.S. 1982. Diagenesis of basalt from the Pasco Basin, Washington. (1) Distribuition and composition of secondary mineral phases. J. Sed. Petrol., 52:595-614.

CALDASSO, A.L. 1965. Geologia da argila de Boa Vista. Recife, Sudene-DRN. 18 p. (Série Especial 2).

CALDASSO, A.L. 1979. Novas consideraçóes sobre a gênese e a idade dos depósitos de argila montmoriloníticas da Paraiba. In: SIMP. GEOL. NORDESTE, 9, Natal, 1979. Atas... Natal, SBG. v. 7,p. 619.626 .

COOLEY, W.W. \& LOHENS, P.R. 1962. Multivariate procedures for the behavioural sciences. New York, Willey. $211 \mathrm{p}$.

EGGLETON, R.A.; FOUDOULIS, C.; VARKEVISSER, D. 1987. Weathering of basalt: changes in rock chemistry and mineralogy. Clay and Clay Min., 35(3):161 169.

ELSINGER, E. \& SELLARS, J.W. 1981. Evidence for the formation of illite from smectite during burial metamorphism in the Belt Super-Group, Idaho.J. Sed.Petrol., 51:203-206.

GARRELS, R.M. \& MACKENZIE, F.T. I971. Evolution of sedimentary rocks. W.E. Norton \& Co. Inc. 397 p.

GOPINATH; T.R.; SCHUSTER, H.D.; VASCONCELOS, E.; FIITOSA, R 1979. Análise ambiental dos arenitos associados com bentonita de Boa Vista, Parafba. In: SIMP. GEOL. NORDESTE, 9. Natal, 1979. Atas... Natal, SBG. v. 7, p. 215-218.

GOPINATH, $T$ R.; SCHUSTER, H.D.; SCHUCKMANN, W.K. 1981. Modelo de ocorrência e gênese da argila bentonítica de Boa Vista, Campina Grande, Pará́ba. Rev. Bras. Geoc., 11(3):185-192.

GRIM, R.E. 1968. Clay mineralogy. 2 ed., New York, McGraw-Hill. $596 \mathrm{p}$.

GRIM, R.E. \& GUVEN, N. 1978. Bentonite - Geology, mineralogy, properties and uses. New York, Elsevier. $255 \mathrm{p}$.

HAY, R.L. \& JONES, B.F. 1972. Weathering of basaltic tephra on the island of Hawail. Geol. Soc. Am. Bull., 83:317-332.

HEIN, J.R. \& SCHOLL, D.W. 1978. Diagenesis and distribution of late Cenozoic volcanic sediment in the Southern Bearing Sea. Geol. Soc. Am. Bull., 89:197-210.

KING, L.J. 1969. Statistical analysis in geography. New Jersey, Prentice Hall. $288 \mathrm{p}$.

KLOVAN, J.E. \& BILLINGS, G.K. 1967. Classification of geological samples by discriminant-function analysis. Can. Petrol. Geol. Bull, 15:313-330.

KOIIWADA. 1987. Minerals formed and mineral formation from volcanic ash by weathering. Chem. Geol., 60:17-28.

LOUGHNAN, F.C. 1969. Chemical weathering of the silicate minerals. New York, Elsevier. 154 p. 
MILLOT, G. 1970. Geology of clays. New York, SpringerVerlag, $429 \mathrm{p}$.

PIERCE, J.W. \& SIEGEL, F.R. 1968. Quantification in clay mineral studies of sediments and sedimentary rocks. J. Sed. Petrol., 39:187-193.

PINTO, C.G. \& PIMENTEL, E. 1968. Consideraçōes geo-econômicas sobre os depósitos argilosos de Boa Vista, PB. Recife, DNPM. 20 p. (Relatório técnico).

ROSS, C.S. \& HENDRICKS, S.B. 1945. Minerals of the montmorilonite group. U.S. Geol. Surv. Prof. Paper., 205B:23-79.

SOUZA-SANTOS, P.S. 1970. Estudo tecnológico de argilas montmoriloníticas do distrito de Boa Vista, município de Campina Grande, Paraiba. São Paulo, Escola Politécnica da USP, 63 p. (Tese para concurso à Cátedra 28).
SOUZA-SANTOS, P.S. 1975. Tecnologia de argilas. São Paulo, Edgard Blücher-EDUSP, $340 \mathrm{p}$.

SLAUGHTER, M.\& EARLY, J.W. 1965. Mineralogy and significance of Mowry bentonites, Wyoming. Geol. Soc. Am., 116 p. (Special Paper).

SOKOLOV, G.U. 1966. Tertiary tuffaceous formations in the Doneto Basin. Geol. Zh. Akad. Nauk. Ukr. SSr., 25(4):90-94.

WALKER, G.L.P. 1960. Zeolite zones and dike distribution in relation to the structure of the basalts of easternn Iceland. J. Geol., 58:515-528.

MANUSCRITO 471

Recebido em 10 de agosto de 1987 Revisẩo aceita em 26 de maio de 1988

Com o aperfeiçoamento do transporte e acesso mais fácil a outras partes do mundo, os geólogos começaram a examinar rochas distantes de seus lugares nativos, para importar novos dados e para exportar suas idéias.

Charles L. Drake, 1987, Episodes 10 (4): p.235. 